\title{
Systematics of Intelligent Transport Systems Services
}

\author{
Jacek Oskarbski ${ }^{1,}$, ,Tomasz Marcinkowski ${ }^{1}$, Krystian Mówiński ${ }^{1}$, and Karol Żarski ${ }^{1}$ \\ ${ }^{1}$ Gdansk University of Technology, Faculty of Civil and Environmental Engineering, Gdansk, Poland
}

\begin{abstract}
Recent years have seen a more intensified deployment of Intelligent Transport Systems (ITS) in Polish cities. Work is also underway on the implementation of ITS on the national roads within the National Traffic Management System (KSZR). The research project RID-4D (part of Road Innovations), is designed to fill the gap, which is the lack of systematics of ITS services in Poland. The paper presents a proposal of ITS services systematics, which was developed based on an analysis of key international standards. FRAME architecture and American standards were the basis for the preparation of a standard scheme of ITS services. The results of the work on the KSZR architecture as well as local and regional architectures of urban systems were also taken into account.
\end{abstract}

\section{Introduction}

The main objective of the RID 4D research project is to investigate how ITS services can improve road safety. Because Poland does not have an ITS architecture, ITS services first had to be identified, systematised and grouped to support further analyses of how single services or groups of services can influence road safety and efficiency in Poland. Existing deployments in Polish cities (such as ITS functions and services which are part of the TriCity TRISTAR system) [1] and the documentation of the planned KSZR had to be taken into account. Before proceeding with the ITS services systematics, key publications on ITS architecture and services were analysed [2], [3], [4]. The most important baseline document for preparing the systematics was FRAME, the European architecture paper. The names of the services were considered both from the perspective of user needs (USER NEEDS) and the functionality of the service (FUNCTIONS). Importantly, the planned functional structure of the KSZR was analysed [5]. The end result is a model systematics of ITS services developed in collaboration with the General Directorate for National Roads and Motorways (GDDKiA). Each service comes with a detailed description to ensure clarity and functionality of the particular ITS services.

This article analyses the literature, domestic and international experience on ITS classification in relation to the services (a synthesis of international experience in the systematics of services, diagnosis of service development and worldwide strategies for service management, synthesis of Polish experience - work of the ministry, GDDKiA, local authorities) and how this may help improve traffic conditions and road safety. Finally, a model systematics of services has been developed (divided into structures, categories and

* Corresponding author: joskar@pg.gda.pl 
names) with a description of the functional, logical and physical structure (hardware and teleinformatics).

\section{Studies of literature on ITS services systematics}

\subsection{General definition of an ITS service}

The basic problem of the analysis was to define clearly the term "ITS service". According to the Directive of the European Parliament and of the Council 2010/40/EU of 7 July 2010 on the framework for the deployment of intelligent transport systems in the field of road transport and for interfaces with other modes of transport, it was stated that:

"ITS service" means the provision of an ITS application through a well-defined organisational and operational framework with the aim of contributing to user safety, efficiency, comfort and/or to facilitate or support transport and travel operations; where "ITS application" means an operational instrument for the application of ITS [6]. To conduct a more in-depth analysis of the term and gain a better understanding of how ITS services are systematised, several documents were consulted which set out how this is done in the world, Europe and Poland:

- FRAME (Europe)

- KSZR (Poland - based on FRAME)

- ISO standard

- US architecture - US National ITS Architecture

\subsection{ITS services in the FRAME architecture}

FRAME architecture is now available in its fourth version and covers the following functional areas:

- electronic payment,

- safety, traffic management,

- public transport management,

- driver assistance,

- traveller assistance,

- support for law enforcement,

- fleet management,

- cooperative systems (exchange of information between vehicles and vehicles and infrastructure) [7].

The methodology for designing ITS systems under the European FRAME architecture distinguishes four main stages. For the purposes of the analysis, the first two ones are selected:

1. Identify user requirements [USER NEEDS];

2. Identify the system's functional architecture to ensure that user needs and functions match (taking into account available functions, their delivery and information flows between them) [FUNCTIONAL VIEWPOINTS];

3. Identify the physical architecture by defining sub-systems and modules, their location and flows between them;

4. Identify the architecture of the communications system, i.e. means of information exchange between the different parts of the traffic management system and external entities [2].

As regards the design methodology, the most important element of FRAME is to identify user requirements and the system's functional architecture. For this reason, USER NEEDS 
and FUNCTIONAL VIEWPOINTS were analysed in great detail in the initial part of this work during the stock-taking of services and then when developing the proposed systematics.

The FRAME architecture contains orderly structural groups/areas for the user need branch and functionality branch which come together at the lowest levels of detail (Fig. 1.). This helps to identify the physical and communications architecture at a later stage.

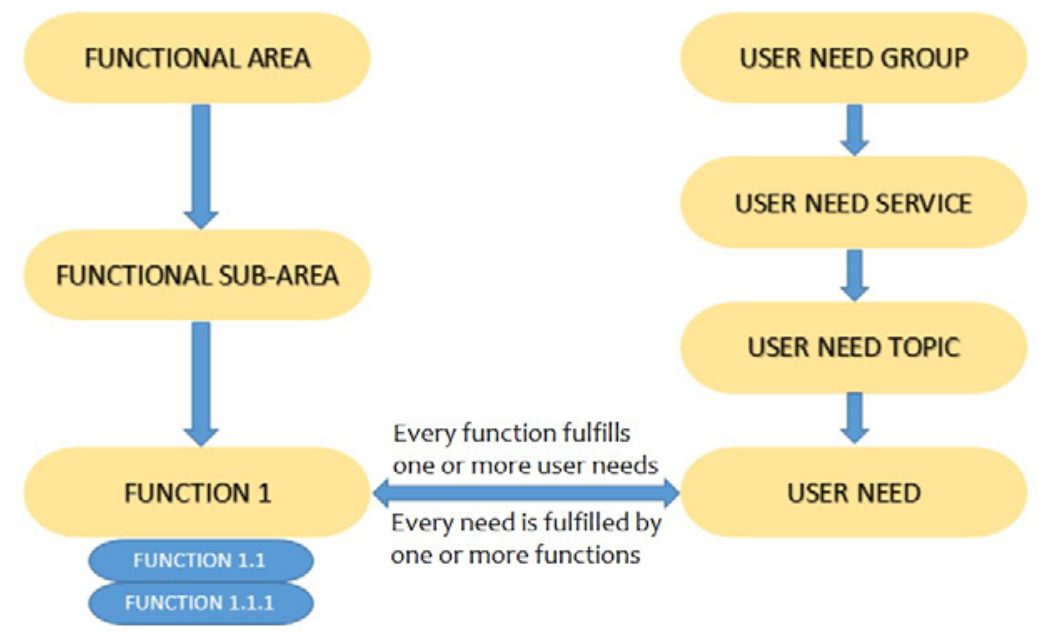

Fig. 1. Relations between user needs and functionalities in FRAME.

According to FRAME a clear-cut definition of an ITS service was not easy due to the specific names of the components of system structures.

FRAME provides the necessary tools for designing ITS architecture which help to define the links between user needs and the functionality of the service. They are called SELECTION TOOL (an application which supports the process of developing ITS architecture for the user) and BROWSING TOOL (an application that allows the user to investigate the structure of the FRAME architecture). The tools and other materials found on the FRAME website helped to identify the links and understand the systemic structure of FRAME which was the basis for creating the model systematics of ITS services.

\subsection{ITS service in US architecture}

A study of the US's National ITS Architecture was conducted as part of the in-depth analysis. The architecture provides the necessary tools for planning, defining and integrating all intelligent transport systems. It defines:

- The functions (e.g. gather traffic information) that are required for ITS

- The physical entities or sub-systems where these functions reside

- The information flows and data flows that connect these functions into an integrated system.

The architecture is divided similarly to the FRAME architecture. The main component is USER SERVICES and USER SERVICES BUNDLE which categorise services into groups [4].

\subsection{ITS service according to ISO}

Another helpful source for developing the proposed systematics was service categorisation in the ISO standard 14813-1:2015 [2]. Services here are also arranged hierarchically:

- ITS Service Domain

- ITS Service Group 


\section{- ITS Service}

The ITS service includes a product or activities that may be supplied to a specific ITS user. This is considered an elementary "building block" of any architecture/implementation.

\subsection{ITS service within the National Traffic Management System}

The next important step was to see how the new systematics would work with the structure of the National Traffic Management System (KSZR) for Poland's national roads developed by the GDDKiA. The main point of reference for developing the system's service architecture was the architecture of FRAME. The GDDKiA is using a dedicated KSZR website to provide a lot of information about the system's general functional and physical architecture based on the European FRAME architecture. The website also gives a description of implementation modules. Key to the work on the systematics was to refer to the modules [5].

The functional architecture consists of descriptions of the functions and flows between them. This is presented in a table and a graphic representation of the functions and flows. The physical architecture divides the KSZR into implementation modules. There are links between the implementation modules, operators and external stakeholders. The functionalities are also described with reference to FRAME. Treating functions as ITS services turned out to be the right approach for the new services systematics [5].

\section{Methodology of work on ITS service systematics}

\subsection{Stage One: Selecting the level of detail with reference to FRAME}

The main point of reference for the new systematics was the FRAME architecture, Europe's leading base material for planning ITS (the KSZR's ITS architecture is an example). Its SELECTION TOOL helps to establish the connections between a need and functionality (activity) to meet that need. Using a database, we can find the details of the relation. The team's main task was to select those components that will best reflect the 3-level detail of service categorisation. While a USER NEEDS analyses showed that it contains the majority of the services, they are designed to provide benefits for the user. This was not a strong enough argument to use in the systematics because despite a clear level of detail, problems could appear later and service functionalities might not be accurately described. A FUNCTIONS oriented approach guaranteed a wide variety of services and a detailed service description. Service categorisation, however, features different levels of detail, which turned out to be a problem. The above approaches were compared and the functional approach was chosen. The problem of the level of detail was solved at a later stage of work on the systematics by grouping analogous functions.

\subsection{Stage Two: Expert method while reviewing FRAME functions}

The functionality approach meant having to analyse thoroughly all ITS functions (more than $300)$ of the FRAME architecture and grouping them in a specific level of detail: category (area) of services $->$ main service $->$ specific services.

Initially, all services were selected for how they affect road safety and traffic efficiency. Using the expert method a preliminary classification was conducted. This started a discussion on some of the problematic functions involved in data collection; should they be classified as a separate service or as an indispensable component of service delivery. Finally, functions were grouped within a single selected specific service. This is reflected in the tabularised version of the model service systematics. 


\subsection{Stage Three: Categorisation and division of ITS services}

In the final stage a tabular three level division of the service was proposed based on the agreed guidelines. For clarity's sake the names are in two languages to avoid any confusion with the FRAME architecture. In addition, each of the specific services comes with one or several FRAME functions in the original numbering. It was important to do that to ensure that no significant function was left out when presenting the procedure for systematics development.

\begin{tabular}{|c|c|c|c|c|c|c|c|c|c|c|c|}
\hline ID & Category & ENG & ID & $\begin{array}{c}\text { Main } \\
\text { service }\end{array}$ & ENG & ID & Specific service & ENG & $\begin{array}{l}\text { FRAME } \\
\text { function }\end{array}$ & 10 & GDDKiA service \\
\hline \multirow{5}{*}{3} & \multirow{5}{*}{ 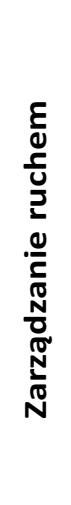 } & \multirow{5}{*}{ 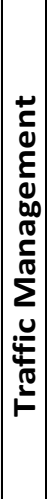 } & \multirow{5}{*}{3.4} & \multirow{5}{*}{ 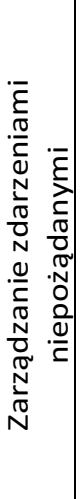 } & \multirow{5}{*}{ 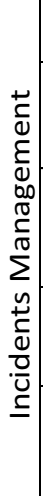 } & 3.4 .1 & Wykrywanie zdarzenia & Detect incidents & \begin{tabular}{|l|}
$3.2 .12 \mid$ \\
3.2 .13
\end{tabular} & & - \\
\hline & & & & & & 3.4 .2 & $\begin{array}{l}\text { Ocena zdarzenia i reagowanie } \\
\text { na nie }\end{array}$ & $\begin{array}{l}\text { Classify, identify } \\
\text { incidents and devise } \\
\text { responses }\end{array}$ & \begin{tabular}{|l}
$3.2 .11 \mid$ \\
3.2 .6
\end{tabular} & & - \\
\hline & & & & & & 3.4 .3 & $\begin{array}{l}\text { Niwelowanie skutków } \\
\text { zdarzenia niepożądanego }\end{array}$ & $\begin{array}{l}\text { Provide incidents } \\
\text { mitigations to traffic } \\
\text { management }\end{array}$ & 3.2 .7 & 4.1 & $\begin{array}{l}\text { Wdrażanie organizacji ruchu } \\
\text { dla zarządzania zdarzeniami }\end{array}$ \\
\hline & & & & & & 3.4 .4 & $\begin{array}{l}\text { Informowanie o szczegółach } \\
\text { zdarzenia niepożądanego }\end{array}$ & Send incident details & $\begin{array}{l}3.2 .14 \mid 3 . \\
2.8 \mid 3.2 .9\end{array}$ & 1.1 & $\begin{array}{l}\text { Informacja o zdarzeniach } \\
\text { drogowych }\end{array}$ \\
\hline & & & & & & 3.4.5 & $\begin{array}{l}\text { Gromadzenie, przetwarzanie i } \\
\text { archiwizacja danych o } \\
\text { zdarzeniach niepożądanych }\end{array}$ & $\begin{array}{l}\text { Manage store of } \\
\text { incident data }\end{array}$ & 3.2 .10 & 3.6 & Krajowy Punkt Dostępu \\
\hline
\end{tabular}

Fig. 2. Fragment of the new services systematics using the example of a main service which is Incidents Management. [8]

In the final stage of work, some names were corrected as necessary and unclassified KSZR services were allocated as appropriate. The figure (Fig.2) shows an example of the new systematics for a main service, i.e. Incidents Management.

To ensure that the services are defined in every detail, each specific service was described on the basis of FRAME original functions, which includes the functional, logical and physical layers. The work has produced a systematics with 10 categories divided into 30 main services and 101 specific services.

\section{Summary and further work}

Developed to study the effects of ITS services on road safety, the Polish systematics of ITS services was largely based on known ITS architectures. An important part of the work was to decide on the level of detail of the services. The structure of the systematics was to help understand the effects of services and groups of services on road safety and traffic performance. The model systematics takes accounts of the ITS services used in Polish cities and in the KSZR. A review of literature was conducted to understand the effectiveness of the services. The proposed systematics of services was the basis for conducting surveys in local authority and central government institutions that are responsible for infrastructure management, road traffic, public transport, emergency and security services. Companies and NGOs involved in ITS were also surveyed. Thanks to the operational experience of the respondents, suggestions have been made regarding the nomenclature of ITS services included in the systematics. The survey results will be presented in future publications. The developed systematics will help to choose the most relevant services in the next stages of research. 


\section{Acknowledgements}

The article is part of the project RID-4D (41) "The impact of the use of Intelligent Transport Systems services on the level of road safety" (OT4-4D/ITS-PW-PGIBDiM-WAT), funded by the National Centre for Research and Development (NCBR) and the General Directorate for National Roads and Motorways - GDDKiA (contract no. DZP/RID-I-41/7/NCBR/2016 of 26 February 2016).

\section{References}

1. J. Oskarbski, Perspectives of Telematics Implementation in Tri-City Transport Systems Management and Planning, in: Commun. Comput. Inf. Sci. Vol. 239, pp. 233-240 (2011)

2. European Intelligent Transport Systems (ITS) Framework Architecture, www.frameonline.eu, (2016)

3. Intelligent Transport Systems - Reference model architecture(s) for the ITS sector - Part 1: ITS service domains, service groups and services, ISO 14813-1:2015(E) 2-nd ed. (Geneva, Switzerland, 2015)

4. Key concepts of the National ITS architecture - Users Services and User Service Requirements, available

at: www.iteris.com/itsarch/documents/keyconcepts/keyconcepts.pdf, (2016)

5. Krajowy System Zarządzania Ruchem, www.kszr.gddkia.gov.pl, (2016)

6. Directive 2010/40/EU of the European Parliament and of the Council of 7 July 2010 on the framework for the deployment of Intelligent Transport Systems in the field of road transport and for interfaces with other modes of transport, (2016)

7. M. Litwin, K. Modelewski, Tworzenie usług dla transportu publicznego w oparciu o europejską Architekturę FRAME, in: VIII Konf. Nauk., (Poznan, Poland, 2011)

8. J. Oskarbski, M. Tomasz, M. Krystian, M. Zawisza, K. Żarski, Systematics of ITS services - periodic report of the project RID-4D: The impact of the usage of Intelligent Transport Systems services on the level of road safety (Gdansk University of Technology, 2016) 